Article

\title{
An appraisal of the Filipino Catholic Devotion to the Black Nazarene in the light of New Evangelization
}

\author{
Joseph Albert DG Reyes, MA \\ jdreyes@ust.edu.ph \\ Theology Professor \\ University of Santo Tomas \\ España Blvd, Sampaloc, Manila, \\ 1008 Metro Manila, Philippines
}

\begin{abstract}
Popular devotions are reflections and expressions of the people's faith. They are expressions of how people recognize God in their lives, and as a shared experience, they foster expressions of devotion and thus become a manifestation of prayer. Popular devotions as forms of prayer and worship do not contradict the Sacred Liturgy but are acknowledged as legitimate by the Apostolic See. Moreover, popular devotions, in general, lead to the cultivation of some values. One of the most popular devotions among Filipino Catholics is the devotion to the Black Nazarene, a life-sized statue of Jesus Christ kneeling in one knee carrying the cross-dressed in a maroon robe. His face is marked with wounds and blood. His head is crowned with thorns with three gold-plated metal rays on the top of his head, with his eyes looking up to heaven. The Black Nazarene devotion balances Christology from below and above, i.e., Christ does not remain crucified. Instead, he brings the hope of resurrection to those who fervently approach him with faith, hope, and love. It suffices to say that the Black Nazarene serves as a means for the Filipino faithful to encounter Christ in their lives. Given this, this paper aims to appraise the Black Nazarene Devotion as a means that contributes to the New Evangelization among Filipino Catholics. More specifically, this paper seeks to answer how the devotion to the Black Nazarene aids Filipino Catholics in their desire to sustain and grow in their faith amidst the crises and problems they are facing.
\end{abstract}

Keywords: Black Nazarene, Popular Devotion, Filipino Catholics, Sacred Liturgy, New

Evangelization

\section{Introduction}

Christianity in the Philippines has spread so many devotions that influenced Filipino cultures. Black Nazarene is one of the many popular devotions in the Philippines that call people into conversion and religious zeal. Devotions serve as one of the ways in evangelizing the Filipino Catholics, reflecting on the lives of the icon, witnessing the miracles, and joining the other faithful to live out the values taught. Devotions have a significant role in strengthening one's faith and relationship with God. However, not all devotees know and understand the backgrounds of their practices, their more profound meaning, and their importance on how it contributes to evangelization. 
According to Bernhard Raas, SVD, popular devotions could be defined as a "collective name for prayers and practices which originated from private initiatives and were not accepted as an official liturgy of the Church. Many of them are highly recommended and approved by the ecclesiastical authority."(Raas 1992). It has different forms of prayer; its focus could either be by reciting the prayers or by practice like pilgrimages and wearing of medals. Devotions come from "below," which means it originated from someone and sometimes unknown. These practices are not obligatory to everyone. (Raas 1992)

Popular devotions are much more rooted in a Christology from below (means its starting point is from the historical Jesus. Historical Jesus and generic approach start from below, but we still uphold full divinity and full humanity of Jesus). They come from the people themselves, touching their lives and inspiring them. Christology from above means it is an approach that starts from the dogmatic claims of our faith. Devotion is one of the Christian ways of trying to reach and experience God in some simple ways of forms of prayer and practices like touching the robes and body parts of the statues of saints, attending novena masses, fiesta mass, pilgrimages, offering intentions, etc. Others knew them as popular spirituality, popular religiosity, a religion of the people, and the widespread religious sense. (Lindsay 1983) The focus permanently resides in the word "Popular," which means the "People," or the "People of God." These devotions are continuously "loved" and "cherished" by the people. (Raas 1992)

It is essential to note the place of devotions in the evangelization of the Catholic Church. This paper focuses on the devotion to the Black Nazarene in the light of the new evangelization. It aims to answer the following questions: What is the Black Nazarene devotion? What are the historical and sociological aspects of the Black Nazarene? What are the teachings of the Catholic Church regarding popular devotions? How does the Black Nazarene devotion serve as a means that contributes to the New Evangelization among Filipino Catholics? What is good about popular devotions? What are the negative practices or beliefs that need to be clarified? Lastly, what are the recommendations to the people regarding the devotion?

\section{- History of the Devotion in the Philippines}

Devotions are deeply rooted in every experience of the people. Lawrence $S$. Cunningham said, "Many of these devotional practices have profound roots in common culture." (Cunningham 2001) These devotions could also be inherited from the family's ancestors or already common practice within the family.

Part of the Spanish colonization in the Philippines is their introduction of Christianity to the Filipino people on the island of Cebu. According to legend, the Spaniards helped treat the ill grandson of Chief Humabon, hence allowing the baptism of the tribe. (2016) It was also said that without the intervention of the Spaniards in converting Filipino people into Christianity, the Philippines would be most likely a Muslim country since Muslim Filipinos were already settled earlier in Manila. (Russell 2016) At the event of the Baptism of Chief Humabon and his wife, the Spaniards presented the image of the Sto. Niño which was still located in Basilica del Santo Niño. (Russell 2016) Devotions were first introduced by the Spanish colonizers and became part of what it means to be a Filipino Catholic today. (Granada 2016) Other popular devotions practiced by Filipinos are Holy Rosary, Scapular, the Angelus, Perpetual Help, Sacred Heart, Litanies, Miraculous Medal, processions, May devotions, the devotion of Saints, Sto. Niño, different Marian shrines, the Black Nazarene, and many other forms relating to Mary and Jesus.

History tells us that the Black Nazarene is known to be sculpted by a Mexican sculptor and was transported to Manila on May 31, 1606, during the Spanish period by the first group of the Order of the Augustinian Recollects (OAR) by a galleon. It was first kept in the Bagumbayan church, which is now Rizal Park. It was transferred again to a 
bigger church of the Augustinians in Intramuros in 1608. By order of the Archbishop of Manila, Basilio Sancho Junta y Rufina, the image was transferred in the Quiapo Church under the patronage of Saint John the Baptist. On April 20, 1650, it obtained Papal approval from Pope Innocent X. The image survived many crises like fire in 1790 and 1920 that destroyed the Quiapo Church, earthquakes in 1645 and 1863, and the World War II bombing in 1945. (De Guzman 2019)

Most Filipino devotees do not concern much about its origin or history, but they only focus on their hope that their petitions may be granted. They may be helped in their struggles in life and witness miracles. Other devotees consider practices to be a way for them to share His passion and offer their lives to Him. This devotion could always be why every day, especially during its feast day, is flocked by thousands or millions of people.

Countless people wait in line and try their best to reach the image of the Nazarene. During the procession, people witness blood and sweat. People faint and are injured because of the crowdedness, yet they continue trying to pass their towel to touch the Black Nazarene. Why huge crowds herd at its feast, processions, and shrine? Where did their energy, joy, and devotion coming from?

Sociologist Clifford Sorita said in his article "Understanding the Devotion of the Black Nazarene" that the devotion comes from "a deep-rooted personal experience with the Divine whereby a pilgrim undergoes a direct experience of the sacred, either in the material aspect of miraculous healing and acquisition of various temporal needs or in the immaterial aspect of the inward transformation of spirit and personality."(Sorita 2016) It is a personal and communitarian religious experience. One is immersed with his/her faith trying to express it by participating in different activities and practices. There is a desire in spirit to follow Christ, share in His passion and feel the pain he endured. Through this, the devotee experiences a glimpse or a taste of "heaven," not about the pain but the cleansing experience, their repentance, the joy, and their being with others. (Sorita 2016) It is communitarian since they go with other devotees and share their faith by becoming witnesses of their endurance.

\section{- $\quad$ Religious Piety of the Filipinos}

According to the Catechism for Filipino Catholic states:

We Filipinos are "spirit-oriented." We are noted for our openness to the sacred, the transcendent dimension of life. This natural orientation provides a sound cultural basis for Christian prayer life. It shines through in our natural love for religious celebrations. "Filipino Catholicism has always put great stress on rites and ceremonies. Fiestas, processions, pilgrimages, novenas, innumerable devotional practices, both individual and communitarian, mark the concrete religious practice of most Filipino Catholics." (CBCP, 1997)

For most Catholic Filipinos, especially in the provinces, the Catholic faith is being handed down by the grandparents to their children and grandchildren, conditioning them and motivating them to attend masses and novena of the patron saints of their parishes and to the Blessed Virgin Mary. Their grandchildren usually accompanied the elderlies in the morning masses. They became the channels of faith to their grandchildren and the first to introduce different devotions and vocations.

According to Cesar Granada, Filipinos can recognize their lives to several moments in the saints' lives, devotions to Mary and Jesus. It became an exceptional inculturation of faith to the Filipinos. "For example, the devotion to the Poong Nazareno highlighted the passion and death of Jesus. The pious remembrance of His passion and death emphasized the Paschal mystery in an enculturated way where poverty and hardships in life is a source of holiness and sanctification." (Granada 2016) 


\section{- Biblical foundation}

According to the United States Conference of Catholic Bishops, "Popular devotions cannot be traced directly back to the ministry of Jesus and the practice of the Apostles. Most developed gradually over the years and even centuries as people sought ways of living out their faith. The origins of the more ancient devotions are often rather obscure." (USCCB 2003) Some devotions like the Rosary are usually originated as adaptations of the observances of some particular religious orders. Others were originated as a private revelation, some visions, or messages at a specific individual. (USCCB 2003)

\section{- Church Documents}

Pope John Paul II mentioned in his Apostolic Exhortation, Ecclesia in America (Church in America), that Popular devotion could lead the faithful into conversion, charity, and a more profound sense of their church membership. He also spoke about Popular Devotion as one of the means of "Inculturation" of the Catholic faith. (Pope John Paul II 1999)

Sacrosanctum Concilium no.13 states: Popular devotions of the Christian people are to be highly commended, provided they accord with the laws and norms of the Church, above all when they are ordered by the Apostolic See. Devotions proper to individual Churches also have a special dignity if they are undertaken by the mandate of the bishops according to customs or books lawfully approved. But these devotions should be so drawn up that they harmonize with the liturgical seasons, accord with the sacred Liturgy, are in some fashion derived from it, and lead the people to it, since, in fact, the Liturgy by its very nature far surpasses any of them. (Vatican II 1963)

Sacrosanctum Concilium clarified that such popular devotions must receive approval from the Apostolic See and are subject to the jurisdiction of the Bishop of that place. These devotions must not be over and above the Liturgy but must always help the faithful get closer to God and express their faith. The Church "respects and fosters the genius and talents of the various races and peoples. Anything in these peoples' way of life which is not indissolubly bound up with superstition and error she studies with sympathy and, if possible, preserves intact as long as they harmonize with its true and authentic spirit." (Vatican II 1963)

Directory on Popular Piety and the Liturgy no. 11 stated that the faithful practices regarding devotions must also be respected as Christ's action makes them effective. "The faithful should be made conscious of the preeminence of the Liturgy over any other possible form of legitimate Christian prayer. While sacramental actions are necessary to live in Christ, the various forms of popular piety are properly optional. Such is proven by the Church's precept which obliges attendance at Sunday Mass." (Vatican 2001)

Directory on Popular Piety and the Liturgy states: That harmonious fusion of the Gospel message with a particular culture, which is often found in popular piety, is a further reason for the Magisterium's esteem of popular piety. In genuine forms of popular piety, the Gospel message assimilates expressive forms particular to a given culture while also permeating the consciousness of that culture with the content of the Gospel, and its idea of life and death, and of man's freedom, mission, and destiny.

Catechism of the Catholic Church states: Sacramentals are sacred signs instituted by the Church. They prepare men to receive the fruit of the sacraments and sanctify different circumstances of life... They include both praise of God for his works and gifts and the Church's intercession for men that they may be able to use God's gifts according 
to the spirit of the Gospel. In addition to the Liturgy, Christian life is nourished by various forms of popular piety rooted in the different cultures. While carefully clarifying them in the light of faith, the Church fosters the forms of popular piety that express an evangelical instinct and a human wisdom that enriches Christian life. (CBCP 2011)

\section{Significance of the Black Nazarene Devotion to New Evangelization in the Philippine Context}

Through Second Vatican Council, the Catholic Church learned from the council her very own missionary nature and continuously renewing her way of evangelization throughout the time, adjusting to the signs of the times, and giving weight to the rise of new issues concerning the World and in the Church's way of life. The need for evangelization was emphasized in the Church's document "ad Gentes" (to the World). The United States Conference of Catholic Bishops said: "Church's ad Gentes ('to the world') mission given to her by Christ is the proclamation of the Good News to those who do not know him. The historical and social circumstances of the twentieth century prompted the Church to renew her mission to evangelize." (USSCB 2012)

It was given importance again by Pope Paul VI in his writing, Evangelii Nuntiandi, as he stated one of the purposes of the Church's existence: to evangelize, preach and teach, and be a channel of God's grace and forgiveness. (Pope Paul VI 1975)

Saint John Paul II renewed the call for evangelization in the spirit of the Second Vatican Council. Saint John Paul II first used the term "New Evangelization" in 1983, addressing the Catholic Bishops of Latin America in Haiti. "The commemoration of the half-millennium of evangelization will gain its full energy if it is a commitment, not to re-evangelize but to a New Evangelization, new in its ardor, methods, and expression." (Pope John Paul II 1983)

He expounded this call for new evangelization on his document, Redemptoris Missio. He gave three situations of evangelizations, namely: first, evangelization to those who do not know the faith (ad Gentes), secondly, to communities who already received the faith, they become the carrier of the activities of the Church and pastoral care, and lastly, to the Christian Communities that "have lost a living sense of the faith, or even no longer consider themselves members of the Church, and live a life far removed from Christ and his Gospel. In this case, what is needed is a "new evangelization" or a "reevangelization." (Pope John Paul II 1990)

Here, the Black Nazarene in the Philippines enters with its ardor and passion. The influence of the devotion must not remain on just being a mere attraction but must lead to conversion and renewal of faith and love to God and others. The New Evangelization does not only mean carrying out the Gospel but also deepening of one's relationship of the faithful and the Church, application of the teachings in the Second Vatican II, and inculturation of what is already present, accompanying every faithful towards Christian way of life leading them to repentance and love of God.

The New Evangelization does not seek to invite people to experience only one moment of conversion but rather to undergo the gradual and lifelong process of conversion: to draw all people into a deeper relationship with God, to participate in the sacramental life of the Church, to develop a mature conscience, to sustain one's faith through ongoing catechesis, and to integrate one's faith into all aspects of one's life. (USCCB 2005)

During Pope Benedict XVI, he also called the Church to evangelize through dialogue with modern culture and acknowledged the arising crisis brought on by secularization. "To aid the Church in re-proposing the faith to modern society, Pope Benedict XVI established the Pontifical Council for the Promotion of the New Evangelization on September 21, 2010, and proposed that the New Evangelization be the focus of the next Synod of Bishops." (USCCB 2012)

Pope Francis acknowledged the need for renewal of faith and the continuous conversion of the faithful. He gave emphasis and the goodness of popular devotions as a 
starting point and as part of new ways of evangelizations: Each culture and social group need purification and growth. In the case of the popular cultures of Catholic peoples, we can see deficiencies that need to be healed by the Gospel: machismo, alcoholism, domestic violence, low Mass attendance, fatalistic or superstitious notions that lead to sorcery, and the like. Popular piety itself can be the starting point for healing and liberation from these deficiencies. (Pope Francis 2013)

Popular devotions are mostly reflections and expressions of the people's faith. They undergo a process of recognition of God in their lives and their current situations and to people of the same experience. Their similar experience of God creates a certain expression of devotion and becomes the manifestation of their worship through their prayers. These prayers and worship are not in contradiction with Liturgy, recognized by the Apostolic See. Popular Devotions in general lead to the formation of some values like "thirst for God, generosity in giving to the point of heroism, a profound sense of God's providence and constant and loving presence, and the cultivation of a sense of interiority." (Herrera 1985)

Pope Francis mentioned in his Exhortation, Evangelii Gaudium: Genuine forms of popular religiosity are incarnate since they are born of the incarnation of Christian faith in popular culture. For this reason, they entail a personal relationship, not with vague spiritual energies or powers, but with God, with Christ, with Mary, with the saints. These devotions are fleshy; they have a face. They are capable of fostering relationships and not just enabling escapism. (Pope Francis 2013)

The Black Nazarene serves as a new way of evangelization to Filipino Catholics. According to CNN Philippines, around four million devotes attended the procession of the Black Nazarene. (CNN 2016) CNN Philippines added, "Filipino Catholics venerate the Black Nazarene with the belief that the image can bring miracles, as it has endured fires that destroyed its home church, two earthquakes, floods, and even bombings from the World War II." (CNN 2016)

The miraculous stories it was said to bring about mostly deal with health, like 71year-old Virginia Cantos, diagnosed with tongue cancer but didn't have to go through after finishing nine days of the novena to the Nazarene. Again, the figure is also known for granting the wish of numerous couples to have a child through conception or adoption. (Gomez 2020)

For the upcoming celebration of 500 years' presence of Catholic Faith in the Philippines, the Black Nazarene has already considered a gift to Filipinos in strengthening their faith and closeness to God. Having been enculturated in the Filipino Catholics' lives, the Catholic Faith always finds its place in the hearts and minds of devotees. The Black Nazarene became already a part of the lives of the faithful, renewing them from their faith and purifying them from their doubts, trials, and daily Christian lives. Pope Francis acknowledged the importance of such devotion in the process of enculturation and evangelization of faith in the culture of a community.

Once the Gospel has been enculturated in a people, in their process of transmitting their culture, they also transmit the faith in ever new forms, hence the importance of understanding evangelization as enculturation. Each portion of the people of God, by translating the gift of God into its own life and following its genius, bears witness to the faith it has received and enriches it with new and eloquent expressions. One can say that "a people continuously evangelizes itself." Herein lies the importance of popular piety, a true expression of the spontaneous missionary activity of the people of God. This is an ongoing and developing process, of which the Holy Spirit is the principal agent. (Pope Francis 2013)

Devotees of the Black Nazarene are usually the poor, those suffering from different kinds of sickness, and those answered in their prayers. The common people (poor) and usually men shared their sorrows with Christ carrying his Cross. The devotion to the Black Nazarene is different because it is Jesus Christ himself, whom the devotee adores. People are kept on coming back because of their faith, giving thanks to Him, and 
expressing their gratitude to God by their passion for devotion. They believe that because of their devotion, their petitions were granted. In exchange for it, they wanted to repay by participating and attending annually to the feast days and special occasions of the Black Nazarene. The Catholic Bishop's Conference of the Philippines stated that: "We see in this Jesus one who can identify with us in our poverty, sufferings, and oppression; one who can reach out to us as a forgiving and healing Savior in our weaknesses and failings." (CBCP 1997)

It is in this religious experience that the concept of "Panata." It is a vow or promise where "devotees and pilgrims would repeatedly come back to renew this spiritual encounter." It was also a challenge to the devotees that even after the experience, their faith and formation must continue in their ordinary lives or else it will just become a "mere fanaticism." (Sorita 2016) The image shows itself as a figure of Christ who is so close to the poor and the suffering that Christ himself was poor who accepted conviction and death on the Cross.

Last 2020 Traslacion, some devotes interviewed about their devotion by Rappler, an online news website based in the Philippines. Different devotees have their reasons for attending Traslacion and devotion to the Black Nazarene. Others attend to show reverence and faith. Others inherited their devotion from their parents and considered it as one of their traditions in their faith. Others give thanks to God and ask for intercessions. Others believed to be drawn by the Black Nazarene inspired the Holy Spirit.

Nanay Bing (Mother Bing), 55, a canteen helper from Makati, said she had been participating in the Traslacion ever since she was a child. She must have attended this for almost 30 years, she said. During this annual religious event, she prays for a complete family. 'I am praying to be reunited with my children because we are separated due to so many problems. Then, to be given the strength to work and surpass the challenges of life.' (Rappler 2020)

Emelita Araw celebrated her 79th birthday while taking part in the procession. She said her mother handed down the devotion to the Black Nazarene. 'I've been a devotee for a long time since the Black Nazarene, and I have the same birthday. Since birth, I was being brought by my mother [to the procession]. I was in a life-and-death situation when I was still a baby; that was why my mother became a devotee. Since then, we have never failed to attend this spiritual gathering every year.'(Rappler 2020)

After the tragic experience of losing a child, 58-year-old Corazon Dela Cruz said her devotion to the Black Nazarene healed and restored her. 'My firstborn died after I gave birth to her. So, after my second pregnancy, I continued my devotion to the Black Nazarene and always made sure to keep it for my children.' 69-year-old Luzviminda Constantino's devotion to the Black Nazarene came as a family tradition that she wanted to continue. 'When my husband passed away, I continued the tradition for him.'(Rappler 2020)

Though not a prayerful and religious person, 32-year-old Karlo Laquindanum from Velasquez, Tondo, admitted he felt the call to seek and touch the Black Nazarene to show his devotion. 'I was just invited to join the procession at first until I got used to the feeling of fulfillment. It makes me happy, especially when I can serve the Lord by participating in the Traslacion. If I can touch it, I'd feel better, and my parents, we'd have a good life every year and that we would be safe.'(Rappler 2020)

Hailing from Calamba, Laguna, 40-year-old Nestor Obin made the journey to Manila to attend this year's Traslacion on Thursday. He did it to give thanks for the blessings he had received. After being infected with tuberculosis, Manong Antonio said 
he remained thankful he was able to recover. I lost weight, just skin, and bones. I was being lifted to be able to eat. This is my way of thanksgiving. When I got sick, I thought I was going to die. I wore the clothes that they gave me until I got well. Manong Enrico, 64, a tricycle driver, said the Black Nazarene gives his life purpose. 'I'm a devotee for almost five years. I'm a devotee because the Black Nazarene gives me a purpose.'(Rappler 2020)

Many devotees of the Black Nazarene believe the statue holds miraculous healing powers. Still, for 54-year-old Mario Francisco, the most rewarding part of joining the annual Traslacion is its way of building stronger family connections. While he is aware that the long procession is sacrificial, joining the Traslacion is worthy because it brings his family and neighbors closer. 'It's not about asking more miracles, but it's more on thanking the Black Nazarene for giving us a durable family connection, good health, and stable life. For me, that is already a miracle,' he said. Aside from the deep religious devotion, Francisco said devotees must learn to ask for miracles and be thankful to the Black Nazarene for reflecting admirable faith in God, which he said serves as an inspiration to everyone. (Kabagani 2020)

Furthermore, on the Black Nazarene, they see a Jesus who is so human, everloving, and willing to stay with them and a God who is so merciful in forgiving them their sins, healing them from their sickness, and liberating them from the society full of biases and classes. The image helps them identify themselves with God, who is also suffering from them, and feel solidarity. It is difficult for the poor to have thought of Jesus Christ as the King, but a God who became man too and redeemed by their sins liberated them from the sufferings they experience, like healing their sickness and preaching the Kingdom of God. Jesus, who is God, became human for Him to be with us. People also take devotion as their chance and a way to express their solidarity with the Christ who offered himself.

Christ, who was carrying the Cross, portrays a God who offered Himself for the forgiveness of sins of all the people. These will always reflect the people that lead them to do the same by bearing their crosses in their lives. The Black Nazarene reminds the faithful that they are not alone in every crisis they have.

The Black Nazarene (Nazareno in the Filipino language) is believed to be one of the miraculous images in the Philippines. It is a life-size statue of Jesus Christ kneeling on one knee carrying the cross-dressed in a maroon robe. His face is marked with wounds and blood. His head is crowned with thorns with three gold-plated metal rays on the top of his head, with his eyes looking up to heaven. It is presently enshrined at the Minor Basilica of the Black Nazarene in Quiapo, Manila. People flock every January 9 to mark its feast day called "Traslacion," meaning the transfer of the Black Nazarene in a procession.

Other traditional practices were revolving around the image, namely: Pahalik (kissing of the statues), Pasindi (lighting of multi-colored candles outside of the Church), Padasal (from the devotee or the Priests), Pabihis (the changing of the garments of the Black Nazarene), Pabendision (sprinkling of Holy Water after masses or the kissing of the hands of the priests), Pahawak (touching of the statues or the garments of the Black Nazarene), Pamisa (Mass Offerings), Pagnonobena (Novena prayers or masses), Pagpasan (Carrying of the wood of the carroza or the rope attached to it), Pagyayapak (walking barefoot during processions), Paglalakad ng Paluhod (processing to the altar on bended knees) (Sorita 2016)

\section{New Evangelization and Popular Devotions}

"The joy of the Gospel fills the hearts and lives of all who encounter Jesus. Those who accept his offer of salvation are set free from sin, sorrow, inner emptiness, and 
loneliness. With Christ, joy is constantly born anew." (Pope Francis 2013) These were our Holy Father's starting words, Francis on his Apostolic Exhortation, Evangelii Gaudium, with its central theme: On the Proclamation of the Gospel in Today's World. With full awareness of the changing course of time, development, and different influences happening in the World. Pope Francis invited the faithful to a renewal of their profession of faith amidst the changes happening around them and encourage them to respond to the need to continuously evangelize the World and open themselves to encounter the Lord. In his Exhortation, he mentioned that "Whenever we make an effort to return to the source and to recover the original freshness of the Gospel, new avenues arise, new paths of creativity open up, with different forms of expression, more eloquent signs and words with new meaning for today's World. Every form of authentic evangelization is always 'new."' (Pope Francis 2013)

Among the new ways of approaching the faith is through popular devotions flourishing within particular areas. The Black Nazarene contributes to the newness of the Gospel and unique way of evangelization. As for the Black Nazarene, Jesus consistently portrays a ray of hope for faithful to be converted from their sins, always invites the believer to follow God's will as he fulfilled it by his very death on the Cross. Black Nazarene, an image of Jesus carrying the cross journeying to the Calvary, fulfilling God's will to save us from our sins, is always inviting us to follow Him on the way. Through the devotion to the Black Nazarene, as Pope Francis said: "The Church, in her maternal concern, tries to help them experience a conversion which will restore the joy of faith to their hearts and inspire a commitment to the Gospel." (Pope Francis 2013) People in different places join the crowd to experience an internal conversion through devotion. Popular devotion serves as a new form of evangelization.

National Directory for Catechesis mentioned: "The prayers, popular devotions, and liturgies of the Church form the basis of 'Catholic culture'; they allow for the community to pray together in a common language and contribute to one's continuing faith development." (USCCB 2005)

With every effort of the Church to draw people to Christ, the Holy Spirit is at work in inspiring them to convert and build the Kingdom of God through Popular devotions. The Church is missionary by its nature. (Pope John Paul II 1990) The Church serves as an evangelizing community. The Church takes the first step of calling the faithful, supporting them, and celebrating the Paschal Mystery with them. (Pope Francis 2013) Pope Francis in his Exhortation, Evangelii Gaudium, mentioned that an evangelizing community gets involved by word and deed in people's daily lives; it bridges distances, it is willing to abase itself if necessary, and it embraces human life, touching the suffering flesh of Christ in others.

Evangelization is a call for conversion. Devotion to the Black Nazarene is a call for faithful to conversion, continuous renewal of faith, repentance from sin, and living out of Christian values with the example of Jesus' actions. "The proclamation of the Word of God has Christian conversion as its aim: a complete and sincere adherence to Christ and his Gospel through faith. Conversion is a gift of God, a work of the Blessed Trinity."(Pope John Paul II 1990) A devotee should not remain to evangelize by attraction, which means participating in different activities of the Black Nazarene without understanding them and without total change of heart. During the feast day of the Black Nazarene, many people are joining yet; the question is how many among them understand what they are doing? A lot of people attend, and how many will remain to evangelize fully? That means they will carry out the invitation of conversion in their daily lives. 


\section{Conclusion}

\section{Insights}

In the light of the New Evangelization, there are prevailing problems regarding devotions in general and the Black Nazarene that challenge the ministers and pastoral leaders. There is always a need for renewal and purification to avoid confusion and conflicts with faith. Popular devotions are loved much by the people and readily appreciated because of their lively component that could easily be adapted more than Liturgy, seemingly experienced as tedious and limited. Liturgy seems to be so far and unattractive to ordinary people looking for consolation. (Sorita 2016) Most devotions have their days in a week where there will be novena or mass in honor of the image, which for others becomes more special than that of Sunday mass celebration. Others faithfully attend the special practices/festivals allotted to the devotion rather than Liturgy itself.

Over-emphasizing the devotion leads the faithful into some misconceptions of their image of God as there is a promise attached to the devotion, the person fulfills the ritual/ practice to gain favor on God, "I do something so that God will give me."(Raas 1992) The faithful narrows down his/ her understanding of God, having a false image of God who rewards whoever does/practice something and receives nothing for those who do nothing. It changes the motivation of the faithful.

The Catholic Bishops' Conference of the Philippines mentioned: But the very intensity of these devotions to the suffering Christ, unfortunately, leads at times to exaggerations, and even superstitions. "We must have the courage to correct what leads to fanaticism or maintains people infantile in their faith" (PCP II 175; cf. 12). These pious practices can give a very one-sided image of Christ which tends to enslave the devotees rather than heal and liberate them...What, then, is the true meaning of Christ's suffering and death for us, Filipino Christians of today? One "piously" makes suffering something to be sought in itself. The other, in worldly fashion, sees it as something to be avoided at all costs. Both gravely misunderstand the authentic Christian approach to suffering and death. (CBCP 1997)

Having enough education is the best solution to the problem. Learning from its history and earlier practices will give the faithful a stronger conviction of their devotions. Pope Francis said: "we need to be realistic and not assume that our audience understands the full background to what we are saying, or is capable of relating what we say to the very heart of the Gospel, which gives it meaning, beauty and attractiveness." (Pope Francis 2013) Giving the devotees ample time to catechize them, explaining the basic teachings of faith, Liturgy, basic concepts of God's images and devotion, incorporating them in their sermons, recollections, talks, and pastoral visits, giving symposium and theological hour concerning the Black Nazarene.

Popular devotions, in general, are influencing a lot of faithful in the strengthening of their faith. Some have their devotions inherited from their parents, or others vowed to practice such devotion for reasons they associated, like healing from sickness or becoming successful in life. For some faithful, they follow devotions without having a grounded knowledge about the practices. Problems or dangers arise when there is already an over-emphasis and attention of the devotion than the Liturgy itself when there is no real transformation in their lives, as Fr. Bernhard Raas, SVD said. (Raas 1992)

He added some dangers inherent to popular devotions in general that could also be the same with the devotion to the Black Nazarene like the following: They can be onesided. As such, they can cause people to develop false priorities and values. There is also the danger of too much subjectivism, externalism, and sentimentalism. Popular 
Devotions can give a wrong feeling of security in the presence of the living God. There is the danger that popular devotions quickly degenerate into magical or superstitious practices or even idolatry. Popular devotions can be abused for other purposes like moralizing or didactic intentions. (Raas 1992)

There were other surrounding stories about the Black Nazarene that until now are believed by some Filipinos. It was popularly believed that the original color of the Nazarene was white. Still, because of the fire that broke down in the ship during its transportation to the Philippines, the Nazarene was covered with smoke that turned it into black. According to Msgr. Sabino A. Vengco, Jr., who was interviewed before regarding the Black Nazarene, said that "myths are surrounding the devotion to the Black Nazarene." He also noted that "the ignorance surrounding the Nazareno is remarkable." (De Guzman 2015) Msgr. Vengco had been to Mexico and had his research. Based on his research, he said that the wood used is called Mesquite, popularly used by Mexican. "The core of the wood is black, which could be like the Philippine Kamagong," he continued. (De Guzman 2015)

\section{Obligations}

Pastoral leaders should carefully watch and analyze some practices given more priority than the Liturgy and study the best action they should take. The Philippines' Black Nazarene image always attracts and gathers thousands, millions of people in its every feast day and other special occasions. Regarding this particular devotion, there were many mythical beliefs and prevailing ignorance about it, which must be corrected according to theologian Msgr. Sabino A. Vengco, Jr. He clarified that it is wrong to celebrate its feast on January 9 as it is "out of season" in the Liturgical calendar. January 9 is still part of the Christmas season. Msgr. Vengco asks: "How can you be celebrating the birth and the coming of Jesus when already he is there bowed down beneath the weight of the cross?" (De Guzman 2015) He continued by saying that the celebration is "in violation of the fundamental principle that any popular devotion must harmonize with the liturgy and must lead the people, the faithful, into the liturgy." (De Guzman 2015)

Devotees should always be advised and reminded to avoid any excessive practices and expressions that would harm themselves and are not demanded by anyone. Different gestures and observations equipped with the understanding and background knowledge are exemplary. A word grounded in faith and trust in God is good, but too much exaggeration to the point of getting hurt must be reflected upon as what always happens in the event "Traslacion." Msgr. Vengco also explained that January 9 transferred the image from Intramuros to Quiapo, which has no connection to the image portrayed. The Black Nazarene depicting Christ carrying the Cross initially during the Spanish era is celebrated during the Lenten Season and must be as Msgr. Vengco stated. He was also concerned about the Black Nazarene's excessive practice that already became "superstitious, fanatical and even idolatrous." Most people are eager to touch the image during the procession, even throw their towels, and wipe the image.

Vengco laments today's form of devotion, "when people, blindly, would simply want to touch." Among the popular forms of devotion to the Nazareno is the "pahalik," which involves kissing the feet (or any part) of the Nazareno. Vengco says, "Touching is important, but if it is the extent of your religiosity, then it is more magical and superstitious than anything else." Even foreigners were lining up to experience the Black Nazarene pahalik. (De Guzman 2015)

It is a challenge for the faithful to be evangelized not only by attraction but by conversion. Saint John Paull II said: "Dialogue leads to inner purification and conversion which, if pursued with docility to the Holy Spirit, will be spiritually fruitful." (Pope John Paul II 1990) 
What are the tasks of the Church to keep the fire on devotions and contribute to the new evangelization? It should all begin with the ministers and pastoral leaders taking care of the images and other priests and catechists. Evangelization should start with the leaders. Saint John Paull II said: "We cannot preach conversion unless we have converted anew every day." (Pope John Paul II 1990) Evangelization through devotion must always lead the faithful to conversion, which should happen first among the leaders. Having a positive attitude towards popular devotions, specifically the Black Nazarene, must also be considered. Having great respect and appreciation towards the people and careful observance of their practices and reasons must be given priority to the ministers and pastoral leaders. Why are they practicing them? What are the prevailing reasons for their devotions? With these questions in mind, they will enable themselves to have a mutual understanding of the devotion and the people themselves. (Raas 1992)

Marina Herrera states: Liturgists, pastors, and religious educators must take the time to ponder these religious phenomena, live them and enter into them as humble seekers of broader answers to the questions of what it means to be human. They must also accept the spiritual gifts given to those who are poor in the realization that God freely leads people of different races, cultures, and personal sensitivities into the mystery, which is the inner life of the triune Godhead. (Herrera 1985)

After the observation, a thorough reflection and discernment could begin with the help of theological inquiry and historical research. Only with these methods can ministers and pastoral leaders have the right decision on how to purify, recommend, or even stop such devotion. Excessive practice and ignorance will always lead to superstitions and shallow beliefs. Pastoral leaders and priests should have adequate historical and theological knowledge on devotions such as the Black Nazarene and the beauty of the Liturgy. (Raas 1992)

They should encourage everyone to participate more in celebrating the real presence of God, the Eucharist. Having an active, alive, and participative Liturgy will draw more people to appreciate the Eucharist and other sacraments. Popular devotions are in touch with the people. The Black Nazarene is portraying an image of commonality with others, continuously drawing people towards Him. Ministers and pastoral leaders need to know the people's needs, wishes, and desires, especially the poor. In the celebration of the Liturgy, priests could integrate the needs of the people in the intentions, introductory words, homilies, and prayers of the faithful. (Raas 1992)

What are the obligations and rightful attitudes the devotees must observe? The faithful are always looking for something that could quench their thirst for divinity, the longing for the absolute and healing of their brokenness. They are a people whose love with the Lord usually depends on the external activities they do, like the devotions, and on the outcome or fruit of their faith after the practice. Black Nazarene is a kind of Christology unifying the Christology from below and above. There should always be a balance of the two, a Christ who does not remain crucified but also brings hope to everyone for their resurrection; in the end, having basic catechisms and knowledge of the devotion and Liturgy should always remind what the proper practices of the devotions are and avoid excesses.

Directory on Popular Piety and Liturgy stated: The faithful should be made conscious of the preeminence of the Liturgy over any other possible form of legitimate Christian prayer. While sacramental actions are necessary to live in Christ, the various forms of popular piety are properly optional. Such is clearly proven by the Church's precept, which obliges attendance at Sunday Mass. No such obligation, however, has obtained with regard to pious exercises, notwithstanding their worthiness or their widespread diffusion. Such, however, may be assumed as obligations by a community or by individual members of the faithful. (CDWDS 2016) 
The Black Nazarene is a powerful image of God who is in solidarity with the poor in their poverty and suffering, and it is the same God who gives them hope that someday, their poverty and suffering will end. Conversion, commitment, and renewal to the life of Jesus must always be the end of the devotion; without transformation, the devotion will remain an external activity leading to fanaticism, externalism, and sentimentalism; then, the faithful are just evangelized by attraction.

\section{References}

(CBCP 2011) Catholic Bishop's Conference of the Philippines, Catechism of the Catholic Church. Popular and Definitive ed., Manila: Word and Life Publications, 2011, no. 1677 - 1679.

(CBCP 1997) Catholic Bishops' Conference of the Philippines, Catechism for Filipino Catholics. Manila: CBCP, 1997, no. 1469, $554,555$.

(CDWDS 2001) Congregation for Divine Worship and the Discipline of the Sacraments, Directory on Popular Piety and the Liturgy, Principles and Guidelines, December 2001, Vatican Archive, no. 11, 63.

(CNN 2016) https://cnnphilippines.com/news/2020/1/6/Traslacion-2020-FAQ-.html?fbclid=IwAR2 (accessed on March 26, 2020)

(Cunningham 2001) Cunningham, Lawrence S. "Liturgy and Devotions," The Way Supplement, 2001, p 19.

(De Guzman 2015) https://www.gmanetwork.com/news/lifestyle/artandculture/400551/black-or-white-the-nazarene-and-thepinoy-devotion/story/ (accessed on August 29, 2016)

(Gomez 2020) https://nolisoli.ph/72852/the-chaos-and-beauty-of-traslacion-jgomez-20200101/ (accessed on March 26, 2020) $12,2016)$

(Granada 2016) https://cesarsalad.wordpress.com/2015/03/17/popular-religiosity-in-the-philippines/ (accessed on November

(Herrera 1985) Herrera, Marina. "Popular Devotions and Liturgical Education," Liturgy, 1985.

(Kabagani 2020) https://www.pna.gov.ph/articles/1090484 (accessed March 26, 2020)

(Lindsay 1983) Lindsay, Austin J. "Popular Piety: Link Between Priest and People," Priest, March 1983, p. 40.

(Pope Francis 2013) Pope Francis, Apostolic Exhortation on the Proclamation of the Gospel in Today's World (Evangelii Gaudium), November 24, 2013, Vatican Archive, http://www.vatican.va/content/francesco/en/apost_exhortations/documents/papa-francesco_esortazione-ap_20131124_evangelii-gaudium.html (accessed on February 27, 2020), no. 69, 90, 122, 1, 11, 15, 24,34 .

(Pope John Paull II 1983) Pope John Paul II, Address to CELAM, April 18, 1983, (Opening Address of the Sixth General Assembly of CELAM, March 9, 1983, Port-auPrince, Haiti), L'Osservatore Romano English Edition 16/780, no. 9.

(Pope John Paull II 1990) Pope John Paul II, Encyclical Letter on the Permanent Validity of the Church's Missionary Mandate (Redemptoris Missio), December 7, 1990, http://www.vatican.va/content/john-paul-ii/en/encyclicals/documents/hf_jpii_enc_07121990_redemptoris-missio.html (accessed on March 5, 2020), no. 33, 48, 46, 56, 47.

(Pope John Paull II 1999) Pope John Paul II, Apostolic Exhortation on the Church in America (Ecclesia in America), January 22, 1999, Vatican Archive, http://w2.vatican.va/content/john-paul-ii/en/apost_exhortations/documents/hf_jp-ii_exh_22011999_ecclesia-in-america.html (accessed on September 4, 2016), no. 81.

(Pope Paul VI 1975) Pope Paul VI, Apostolic Exhortation on the Evangelization in the Modern World (Evangelii Nuntiandi), December 8, 1975, Vatican archive., www.vatican.va/ holy_father/paul_vi/apost_exhortations/documents/hf_p-

vi_exh_19751208_evangelii-nuntiandi_en.html. no. 14

(Raas 1992) Raas, Bernhard. SVD, "Popular Devotions Making Popular Religious Practices More Potent Vehicles of Spiritual Growth," Manila: Logos Publications, 1992, pp. 15, 16, 17, 26, 27, 28, 29, 30.

(Rappler 2020) https://www.rappler.com/move-ph/248916-filipinos-catholics-share-stories-behind-devotion-black-nazarenetraslacion-2020 (accessed March 26, 2020)

(Russell 2016) http://www.seasite.niu.edu/crossroads/russell/christianity.htm (accessed on August 29, 2016)

(Sorita 2016) http://www.gmanetwork.com/news/story/550360/opinion/understanding-the-devotion-to-the-black-nazarene (accessed on August 29, 2016)

(USCCB 2003) http://www.usccb.org/prayer-and-worship/prayers-and-devotions/prayers/popular-devotional-practicesbasic-questions-and-answers.cfm (accessed on September 4, 2016)

(Vatican II 1963) Vatican II, The Constitution on the Sacred Liturgy (Sacrosanctum Concilium), December 4, 1963 , no. 13. 